\title{
REACTIVITY OF PHENYLANTHRANILIC ACIDS DERIVATIVES. XXIII. SYNTHESIS AND ACID-BASE PROPERTIES OF 4,5-DYMETHOXY-N-(2'-CARBOXYPHENYL)ANTHRANILIC ACIDS
}

\author{
S.G.Isaev, O.M.Sviechnikova*, A.O.Devyatkina, T.A.Kostina, T.N.Svyatska* \\ National University of Pharmacy \\ 53, Pushkinska str., Kharkiv, 61002, Ukraine. E-mail: medchimia@mail.ru \\ * Kharkiv National Pedagogical University named after G.S. Skovoroda
}

Key words: synthesis; reactivity; $N$-phenylanthranilic acid

\begin{abstract}
The alternative ways of synthesis of new 4,5-dymethoxy-N-(2'-carboxyphenyl)anthranilic acids have been considered nad new ways for their obtaining have been suggested. The structure of the compounds synthesized has been proven by the elemental analysis, IR- and NMR-spectroscopy. The purity has been controlled by the method of thin-layer chromatography. The reactivity of 4,5-dymethoxy-N-(2'-carboxyphenyl)anthranilic acids has been researched by studying the acid-base properties in the binary solvent of dioxane-water (60 vol\% of dioxane). It has been found that the substances synthesized are dibasic subacids, which strength depends upon the nature and position of substituents. The quantitative assessment of the influence of substituents on two reactive centres of the acids synthesized has been carried out by the method of correlative analysis according to the Gamete equation. It has been proven that the reactive centres sensitivity is substantially different and dependent on the substituent distance. In addition, appearance of another reactive centre does not practically influence on sensitivity of the first one. It has been determined that the substances synthesized reveal the anti-inflammatory, analgesic, diuretic, bacteriostatic, and fungistatic effects. According to the classification by K.K. Sydorov the substances synthesized when introducing intragastrically belong to low-toxic compounds ( $D L_{50}>3000 \mathrm{mg} / \mathrm{kg}$ ).
\end{abstract}

РЕАКЦІЙНА ЗДАТНІСТЬ ПОХІДНИХ N-ФЕНІЛАНТРАНІЛОВИХ КИСЛОТ. ХХІІІ. СИНТЕЗ ТА КИСЛОТНО-ОСНОВНІ ВЛАСТИВОСТІ 4,5-ДИМЕТОКСИ-N-(2'-КАРБОКСИФЕНІЛ)АНТРАНІЛОВИХ КИСЛОТ

С.Г.Ісаєв, О.М.Свєчнікова, А.О.Девяткіна, Т.А.Костіна, Т.Н.Святська

Ключові слова: синтез; реактивність; N-фенілантранілова кислота

Розглянуті альтернативні варіанти синтезу нових 4,5-диметокси-N-(2'-карбоксифеніл)антранілових кислот та запропоновані нові способи їх одержання. Будову синтезованих речовин доведено даними елементного аналізу, 14- та ПМР-спектроскопії. Чистоту контролювали методом тонкошарової хроматограффії. Досліджено реакційну здатність заміщених N-(2'-карбоксифеніл)антранілових кислот шляхом вивчення кислотно-основних властивостей у бінарному розчиннику діоксан-вода (60 об\% діоксану). Встановлено, що синтезовані речовини є слабкими двоосновними кислотами, сила яких залежить від природи та положення замісників. Методом кореляційного аналізу проведено кількісну оцінку впливу замісників на два реакційних центри синтезованих кислот за рівнянням Гаммета. Доведено, що чутливість реакційних центрів суттєво відрізняється та залежить від віддаленості замісників. При цьому поява другого реакційного центру практично не впливає на чутливість першого. Було встановлено, що синтезовані речовини проявляють протизапальну, аналгетичну, діуретичну, бактеріостатичну та фуннгістатичну активність. За класифрікацією К.К.Сидорова синтезовані речовини при внутрішньошлунковому введенні належать до класу малотоксичних сполук (ДЛ 503000 мг/кг).

РЕАКЦИОННАЯ СПОСОБНОСТЬ ПРОИЗВОДНЫХ N-ФЕНИЛАНТРАНИЛОВЫХ КИСЛОТ. ХХІІІ. СИНТЕЗ И КИСЛОТНО-ОСНОВНЫЕ СВОЙСТВА 4,5-ДИМЕТОКСИ-N-(2'-КАРБОКСИФЕНИЛ)АНТРАНИЛОВЫХ КИСЛОТ С.Г.Исаев, Е.Н.Свечникова, А.А.Девяткина, Т.А.Костина, Т.М.Святская

Ключевые слова: синтез; реактивность; N-феенилантраниловая кислота

Рассмотрены альтернативные варианты синтеза новых 4,5-диметокси-N-(2'-карбоксифенил)антраниловых кислот и предложены новые способы их получения. Строение синтезированных веществ доказано данными элементного анализа, ИК- и ПМР-спектроскопии. Чистоту контролировали методом тонкослойной хроматографии. Исследована реакционная способность замещенных N-(2'-карбоксифенил)антраниловой кислоты путем изучения кислотно-основных свойств в бинарном растворителе диоксан-вода (60 об\% диоксана). Установлено, что синтезированные вещества являются слабыми двухосновными кислотами, сила которых зависит от природы и положения заместителей. Методом корреляционного анализа проведено количественную оценку влияния заместителей на два реакционных центра синтезированных кислот согласно уравнению Гаммета. Доказано, что чувствительность реакционных центров существенно отличается и зависит от удаленности заместителей. При этом появление второго реакционного центра практически не влияет на чувствительность первого. Было установлено, что синтезированные вещества проявляют противовоспалительную, анальгетическую, диуретическую, бактериостатическую и фрунгистатическую активность. По классификации К.К.Сидорова синтезированные вещества при внутрижелудочном введении следует относить к классу малотоксичных соединений (ДЛ 503000 мг/ке). 
Analysis of the research data [1-11] indicates the widespread use of derivatives of $\mathrm{N}$-phenylanthranilic acids in medicine, pharmacy, industry and various fields of science. $\mathrm{N}$-phenylanthranilic acids derivatives have a wide synthetic and pharmacological potential [1-3, 8-11]. The circumstances above caused the necessity to carry out the synthesis of new 4,5dymethoxy-N-(2'-carboxyphenyl)anthranilic acids, study of their reactivity and biological activity. It will allow to optimize the search for new biologically active compounds of this series and forecast their biological effect.

Substituted 4,5-dymethoxy-N-(2'-carboxyphenyl) anthranilic acids have been obtained by the Ullmann reaction by the interaction of 4,5-dymethoxy-chlorobenzoic acids (1) with o-halogenbenzoic acid (method 1) and by arylation of 4,5-dymethoxyanthranilic acid by o-halogenbenzoic acid (method 2 ) in the medium of $\mathrm{N}$-amylalcohol (method 1A, 2A), DMF (method 1B, 2B), without a solvent (method 1C, 2C) in the presence of copper or copper (II) oxide [1-3]. The same as a counter synthesis of 4,5-dymethoxy$\mathrm{N}$-(2'-carboxyphenyl)anthranilic acids (5) condensation of N-acetyl-4,5-dymethoxyanthranilic acids (3) with substituted o-halogenbenzene acid follow by hydrolysis of $\mathrm{N}$-acyd derivatives has been used (Method 3). In order to increase solubility of copper ions in the aprotic low-polar phase to accelerate the arylation reaction various solvent (Tween-80, sodium salt of oleic acids, stearic acid) added to the reaction mixture in the amount of 3-5 weight percent have been used. The use of sodium oleate as a phase trans- fer catalyst allows to accelerate 1,4 times the arylation reaction (Scheme 1).

The structure and identity of 4,5-dymethoxy-N( 2 '-carboxyphenyl) anthranilic acids have been confirmed by elemental analysis, IR-, NMR-spectroscopy, chromatographic analysis and qualitative reactions (Table 1, 2, 3).

IR-spectra of 4,5-dymethoxy-N-(2'-carboxyphenyl) anthranilic acids (5a-f) are characterized by a number of intense bands, which correspond to the main structural fragments of molecules of the substances synthesized, $v \mathrm{~cm}^{-1}: 3362-3258\left(v_{\mathrm{NH}}\right), 1709-1659\left(v_{\mathrm{C}=0}\right)$, $1591-1570\left(\delta_{\mathrm{NH}}\right), 1235-1206\left(v_{\mathrm{CN}}\right)$. The strong bands of nitrogroup $v \frac{a s}{s} \mathrm{NO}_{2} 1523 \mathrm{~cm}^{-1}$ and $v_{\mathrm{NO}_{2}}^{S} 1351-1350 \mathrm{~cm}^{-1}$ are also characteristic for the spectra of compounds (5a-f).

In the NMR-spectra of acids (5a-f) signals of aromatic protons in the range of 6.50-7.90 ppm have been identified. The proton signals of the secondary amino group appear as a broad singlet in the region of 8.05$11.18 \mathrm{ppm}$. The proton signals of the methoxy group are one or two singlets at $3.60-3.80 \mathrm{ppm}$ (Table 3 ).

As a continuation of a number of papers $[4,12$ 19] related to the study of reactivity of biologically active substituted N-phenylanthranilic acids, dissociation of 4,5-dimetoxy- $\mathrm{N}$-(2'-carboxyphenyl)anthranilic acids (5a-f) has been examined according to the equation.

Ionization constants of 4,5-dymethoxy-N-(2'-carboxyphenyl)anthranilic acids have been determined by potentiometric titration in the binary solvent of dioxane-water ( $60 \mathrm{vol} \%$ of dioxane) at $25^{\circ} \mathrm{C}$ (Scheme 2) $[18,19]$. The given method allows to obtain concen-

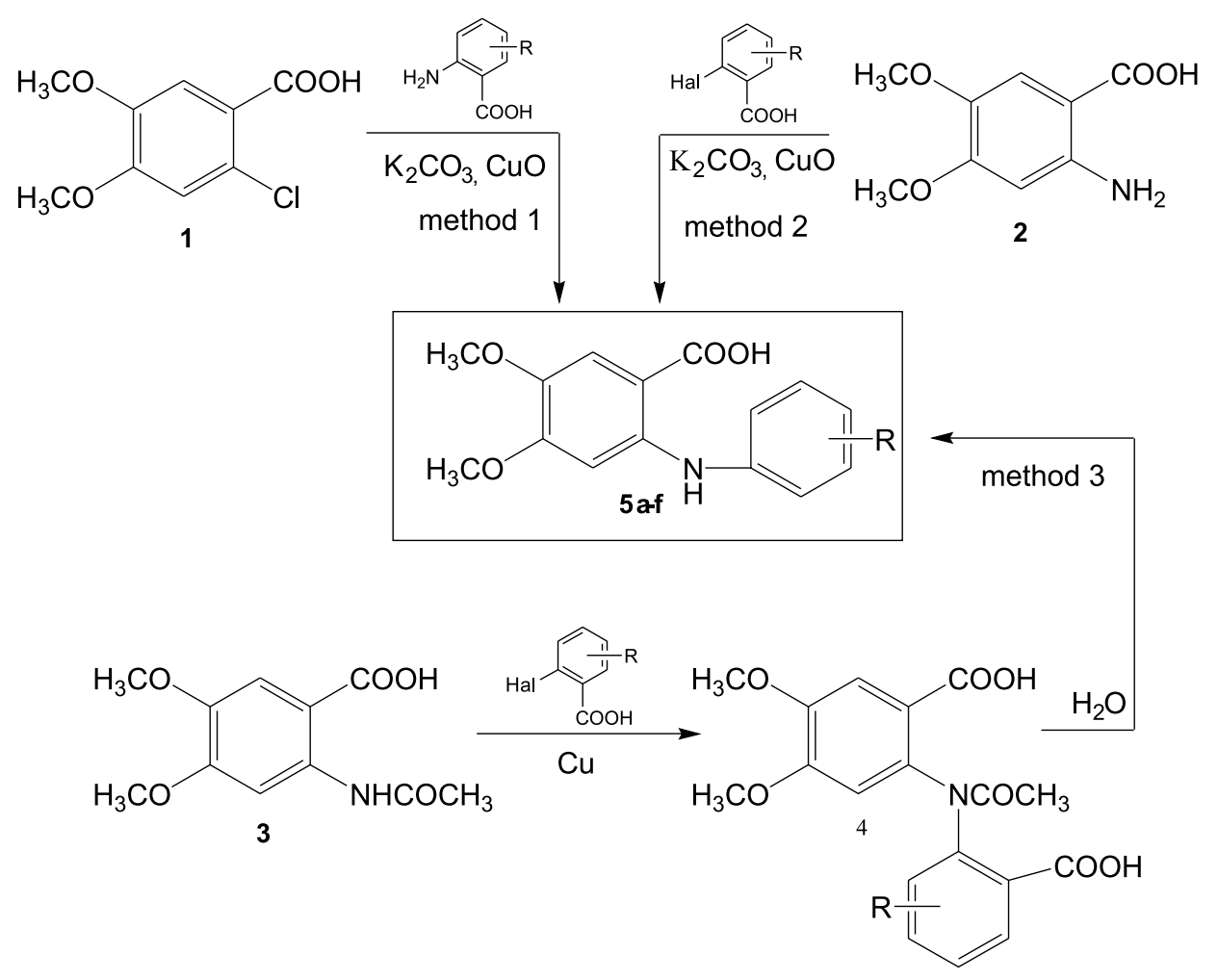




\section{誉}

$\frac{\mathfrak{0}}{\frac{0}{\pi}}$

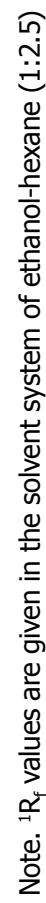

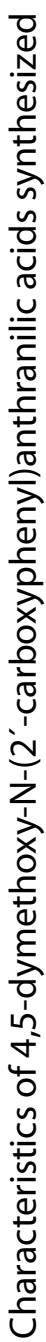

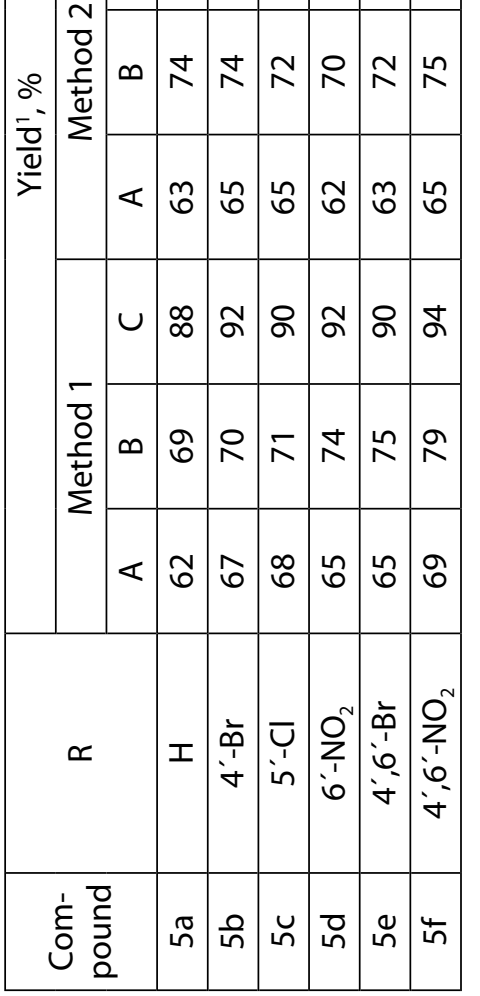

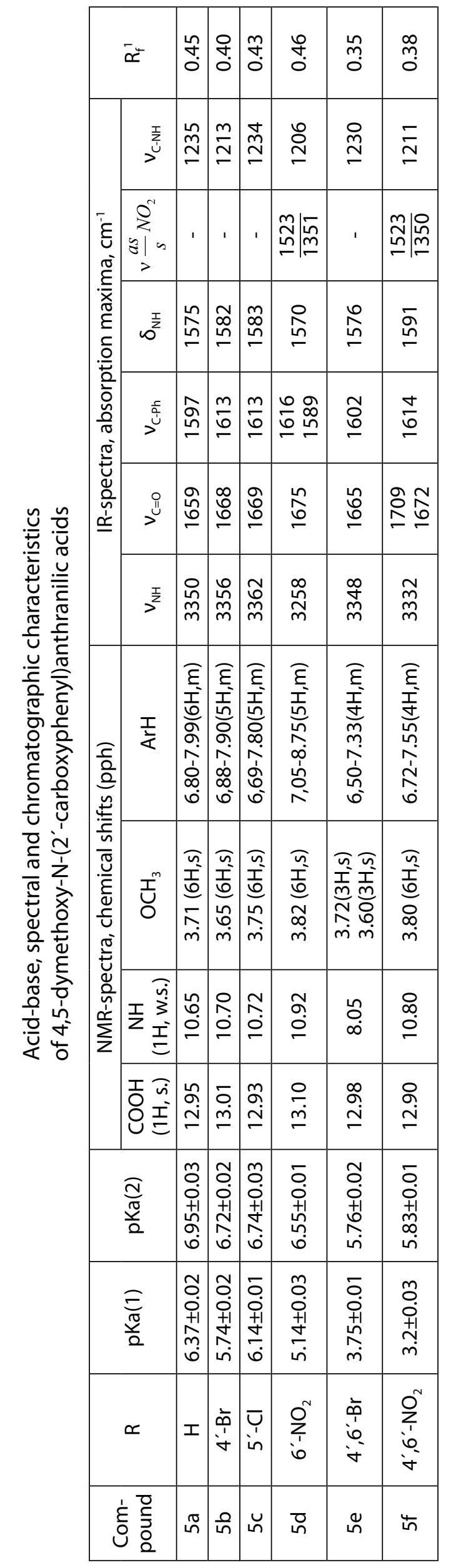


The proton chemical shift value of 4,5-dymethoxy- $\mathrm{N}-\left(2^{\prime}\right.$-carboxyphenyl)anthranilic acids<smiles>[R]c1cccc(NCc2cc(OC)c(OC)cc2C(=O)O)c1C(=O)O</smiles>

\begin{tabular}{|c|c|c|c|c|c|}
\hline \multirow{2}{*}{ Compound } & \multirow{2}{*}{$\mathrm{R}$} & \multicolumn{4}{|c|}{ The chemical shifts (pph) } \\
\cline { 3 - 6 } & & $\mathrm{COOH}(1 \mathrm{H}, \mathrm{s})$ & $\mathrm{NH}(1 \mathrm{H}, \mathrm{w} . \mathrm{s})$ & $\left(\mathrm{OCH}_{3}\right)_{2}$ & ArH \\
\hline $5 \mathrm{H}$ & $4^{\prime}-\mathrm{Br}$ & 12.95 & 10.65 & $3.71(6 \mathrm{H}, \mathrm{s})$ & $6.80-7.85(6 \mathrm{H}, \mathrm{m})$ \\
\hline $5 \mathrm{~b}$ & $5^{\prime}-\mathrm{Cl}$ & 12.93 & 10.72 & $3.75(6 \mathrm{H}, \mathrm{c})$ & $6.69-7.80(5 \mathrm{H}, \mathrm{m})$ \\
\hline $5 \mathrm{c}$ & $6^{\prime}-\mathrm{NO}_{2}$ & 13.90 & 10.80 & $3.80(6 \mathrm{H}, \mathrm{s})$ & $6.72-7.55(4 \mathrm{H}, \mathrm{m})$ \\
\hline $5 \mathrm{~d}$ & $4^{\prime}, 6^{\prime}-\mathrm{Br}$ & 12.98 & 10.70 & $3.65(6 \mathrm{H}, \mathrm{s})$ & $6.88-7.90(5 \mathrm{H}, \mathrm{m})$ \\
\hline $5 \mathrm{e}$ & $4^{\prime}, 6^{\prime}-\mathrm{NO}_{2}$ & 13.20 & 8.05 & $3.72(3 \mathrm{H}, \mathrm{s})$ & $6.50-7.30(5 \mathrm{H}, \mathrm{m})$ \\
\hline $5 \mathrm{f}$ & & 11.18 & $3.60(3 \mathrm{H}, \mathrm{s})$ & $3.80(6 \mathrm{H}, \mathrm{s})$ & $7.10-8.70(5 \mathrm{H}, \mathrm{m})$ \\
\hline
\end{tabular}

tration of pKa only. However, O.M.Svechnikova has proven that these data do not differ practically from thermodynamic pKa [20]. The results obtained are presented in Table 2.

It has been found while pre-studying the titration curves of compounds ( 1 a-f) obtained by the electrometric method that N-phenylantranilic acids under research are dibasic subacids, $\Delta \mathrm{pKa}(\mathrm{pKa}(\mathrm{II})-\mathrm{pKa}(\mathrm{I}))$ less than 4. It allowed to use the Noies's method [21] to calculate $\mathrm{pKa}$.

Analysis of the structure of compounds of the isostructural series has demonstrated that dissociation of 2'-carboxyphenylic radical is stronger comparing with the ionogenic carboxyl group of the anthranilic fragment of the molecule (A) due to the presence of strong acceptor substitutes $\left(\mathrm{NO}_{2}, \mathrm{Cl}, \mathrm{Br}\right)$ in the ring (B), and two donor methoxygroups in the ring (A).

The data presented in Table 2 testify that the nature and position of substitutes have influence upon the acid-base balance of both 4,5-dymethoxy-N-(2'- carboxyphenyl)anthranilic acids. Introduction of electron-acceptor substitutes strengthens dissociation of acids due to the greater anion stabilization. Electron donor substitutes cause an opposite effect. However, the reactive centres sensitivity to the influence of substitutes differs greatly. For balance (I) $-\mathrm{pKa}(6)=1.23$, and for balance (II) - pKa(1) - pKa(6) $=0.40$, i.e. the carboxyl group sensitivity in the ring (B) of 4,5-dymethoxy-N-(2'-carboxyphenyl) anthranilic acids molecules to the influence of substitutes is much greater than sensitivity of the same ionogenic group in the anthranilic fragment (A).

The quantitative assessment of the influence of substitutes in the nonanthranilic fragment of 4,5-dymethoxy-N-(2'-carboxyphenyl)anthranilic acids (5a-f) molecule has been carried out in the range of the principle of linear free energy (LFE) by the Gamete equation (Fig.).

The pKa indices of all compounds studied were used for correlation because schemes of $\mathrm{pKa}(\mathrm{I})-\mathrm{f}(\sigma)$,<smiles>COc1cc(Nc2cccc(C(=O)O)c2)c(C(=O)O)c(OC)c1</smiles><smiles>[R]c1cccc(Nc2cc(OC)c(OC)cc2C(=O)[O-])c1C(=O)[O-]</smiles> 


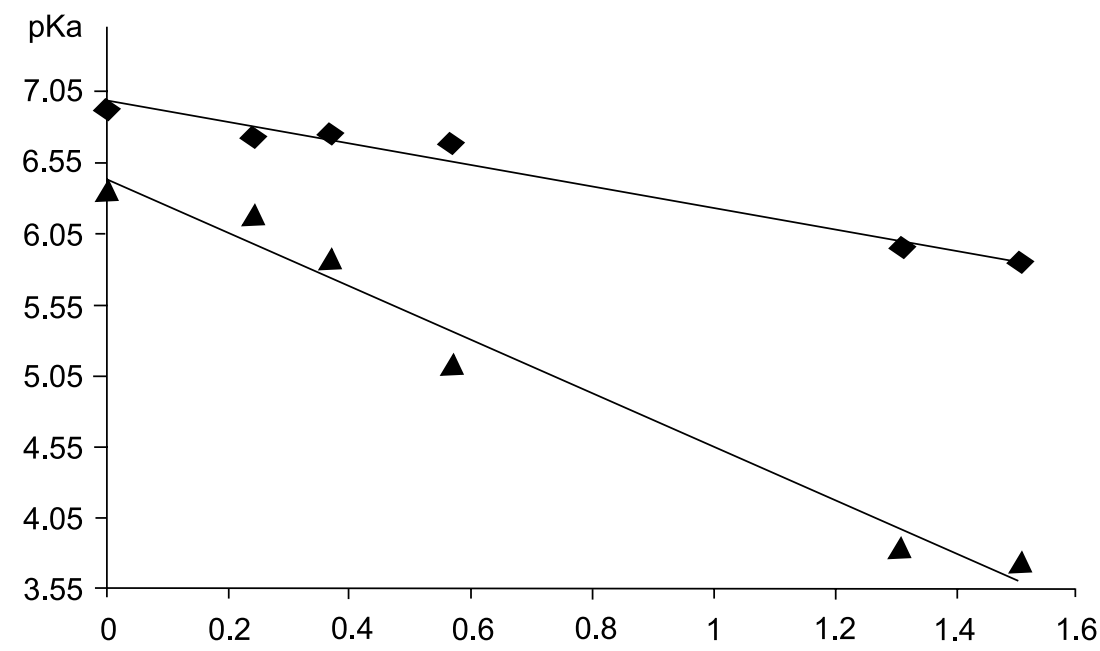

Fig. Dependence of $\mathrm{pKa}(\mathrm{I})-\mathrm{f}(\sigma)$, pKa(II) $-\mathrm{f}(\sigma)$ for 4,5-dymethoxy- $\mathrm{N}-\left(2^{\prime}\right.$-carboxyphenyl)anthranilic acids in the binary solvent of dioxane-water $\left(60 \%\right.$ vol. dioxane) at $25^{\circ} \mathrm{C}$.

$\mathrm{pKa}(\mathrm{II})-\mathrm{f}(\sigma)$ dependence testify their closeness to linearity.

The equations I and II obtained have statistically significant parameters:

$$
\begin{aligned}
& \text { Balance I } \\
& \mathrm{pKa}(\mathrm{I})=(6.43 \pm 0.06)-(1.78 \pm 0.06) \sigma \\
& \mathrm{n}=6 \quad \mathrm{~s}=0.182 \quad \mathrm{r}=0.997 \\
& \text { Balance II } \\
& \mathrm{pKa}(\mathrm{II})=(6.98-0.05)-(0.78-0.05) \sigma \\
& \mathrm{n}=6 \quad \mathrm{~s}=0.154 \quad \mathrm{r}=0.991
\end{aligned}
$$

Comparison of the reaction constants $\rho_{\mathrm{l}}=1.78$ and $\rho_{\mathrm{II}}=0.78$ shows that sensitivity of the reactive centre I (carboxyl group in the ring B) is 2.3 times higher than sensitivity of the reactive centre II (carboxyl group in the ring A). Probably, it is connected with the different distance between carboxyl groups and substitutes in the ring B. It should be noted that appearance of another reactive centre does not practically influence upon sensitivity (within the limits of experimental error $\rho_{\text {II }}$ corresponds to $\rho$ from the other isostructural series of $\mathrm{N}$-phenylanthranilic acids] [12, $13,18-20]$. For balance I sensitivity of the reactive centre is sufficiently high because of closeness of substitutes.

It has been found that the substances synthesized have the anti-inflammatory, analgesic, diuretic, bacteriostatic and fungistatic activity. According to the classification by K.K. Sydorov the substances synthesized when introducing intragastrically belong to lowtoxic compounds $\left(\mathrm{DL}_{50}>3000 \mathrm{mg} / \mathrm{kg}\right)$.

\section{Experimental Part}

Melting points $\left({ }^{\circ} \mathrm{C}\right)$ were measured with the Koeffler's point apparatus and were not corrected. IR-spectra were recorded by the FT-IR Bruker Tensor 27 spectrometer in $\mathrm{KBr} .{ }^{1} \mathrm{H}$ NMR-spectra were recorded by the Varion Mercury 200 (200 Mhz) spectrometer in
DMSO- $\mathrm{d}_{6}$ using TMS as an internal standard (chemical shifts are reported in ppm).

The derivatives of 4,5-dymethoxy- $\mathrm{N}-(2$ '-carboxyphenyl)anthranilic acid were synthesized by a modified Ullmann reaction $[1,3]$. The compounds obtained were recrystallized three times from ethanol and dried to $105^{\circ} \mathrm{C}$ up to the constant weight. The purity of the compounds was checked by thin-layer chromatography.

Reagents. Dioxane used («oscillating») was not purified additionally.

For preparing mixed solutions a fresh boiled bidistillate liberated from $\mathrm{CO}_{2}$ was used [21].

The methods of measurements were similar to those described in [21]. $0.05 \mathrm{M}$ aqueous solution of $\mathrm{KOH}$ purified from $\mathrm{CO}_{2}$ served as a titration agent. The concentration of titration solutions was $0.005 \mathrm{~mol} / \mathrm{l}$. Potentiometric titration was conducted at $25^{\circ} \mathrm{C}$ on an EV-74 ionometer using a glass electrode ESP-43074 and a silver chloride electrode EVL-1 M. The pKa of acetic acid in the binary solvent of dioxane-water solution ( $60 \mathrm{vol} \%$ of dioxane) was determined as a standard (pKa exp. = 7.50; 5.52; 7.49).

The pKa measurements were conducted for each compound independently. The accuracy of the results obtained was estimated by the methods of mathematical statistics (with the reliability level of 0.95) [22].

\section{Conclusions}

1. The preparative methods for synthesis of 4,5dymethoxy-N-(2'-carboxyphenyl)anthranilic acids in the solid phase and in the aqueous medium with the use of a phase transfer catalyst - sodium oleate have been developed.

2. Reactivity of 4,5-dymethoxy-N-(2'-carboxyphenyl) anthranilic acids (6 compounds) has been investigated by studying the acid-base balance of these compounds in the binary solvent of dioxane-water.

3 . It has been found that 4,5-dymethoxy-N-(2'carboxyphenyl) anthranilic acids are dibasic subacids, 
which strength depends upon the nature and position of substitutes.

4. The quantitative assessment of the influence of substitutes on two reactive centres of the acids synthesized has been carried out by the method of correlation analysis according to the Gamete equation.

5. It has been proven that sensitivity of the reactive centres substantially differs and depends on the distance of the substitutes. Herewith, appearance of another reactive centre does not practically influence on sensitivity of the first centre.

6 . The correlation equations $\mathrm{pKa}_{(\mathrm{I}, \mathrm{II})}-\mathrm{f}(\sigma)$ obtained for 4,5- dymethoxy- $\mathrm{N}$-(2'-carboxyphenyl)anthranilic acids allow to predict acid-base properties of the other compounds of this isostructural series and to use them for QSAR-analysis.

\section{References}

1. Ісаєв С.Г., Сулейман М.М., Свєчнікова О.М. // Мед. хімія. - 2010. - Т. 12, №2 (43). - С. 82-86.

2. Ісаєв С.Г., Павлій О.О., Брунь Л.В. та ін. // Ліки. - 2007. - №3/4. - С. 75-79.

3. Ісаєв С.Г. Синтез, реакційна здатність і біологічна активність похідних орто-галогенбензойних, ароматичних амінокислот та акридину: Дис. ... д-ра. фармац. наук. - Х., 2008. - 357 с.

4. Ісаєв С.Г., Свєчнікова О.М., Сулейман М.М. // Фармац. часопис. - 2012. - №3 (23). - C. 12-16.

5. Машковский М.Д. Лекарственные средства. Изд. 15-е, перераб., испр. и доп. - М.: Новая волна, 2005. $1200 \mathrm{c}$.

6. Оптимізація пошуку ефективних лікарських засобів на основі $N$-фенілантранілових кислот: Інформ. лист №193-03 / Укладачі: С.Г.Ісаєв, О.О.Павлій, І.А.Зупанещь та ін. - К., 2003. - Вип. №13 з проблеми «Фармація». - 5 c.

7. Chikina E.L., Isaev S.G., Svechnikova E.N. Proceedings of the IVTN-2004 Computer application in scientific researches IVTN-2004. - P. 31.

8. Lassiani L., Pavan M., Berti F. // Bioorg. and Medicinal Chem. - 2009. - Vol. 17, №6. - P. 2336-2350.

9. Renaud R., Vincent T., Cazoline N. et al. // J. Biol. Chem. - 2004. - Vol. 279, №20. - P. 21160-21168.

10. Tsutomu Nakahara, Akiko Mitani, Maki Saito et al. // Vascular Pharmacol. - 2004. - Vol. 41, №1 - P. 21-25.

11. Xunfeng M., Adam T. August, Christian Wolf // J. Biol. Chem. - 2006. - №7. - P. 142-149.

12. Гайдукевич А.Н., Свечникова Е.Н., Голик Н.Ю // ЖОХ. - 1994. - Т. 64, вип. 10. - С. 1705-1709.

13. Гайдукевич А.Н., Арсеньева Т.И., Свечникова Е.Н., Микитенко Е.Е. // ЖОХ. - 1992. - Т. 62, вип. 62. C. 1589-1591.

14. Ісаєв С.Г., Свєчнікова О.М., Сулейман М.М., Жукова Т.В. // Вісник фармації. - 2012. - №3 (71). - 52-56.

15. Ісаєв С.Г., Свєчнікова О.М., Алферова Д.О. та ін. // Вісник фармації. - 2013. - №2 (74). - С. 45-48.

16. Ісаєв С.Г., Свєчнікова О.М., Павлій О.І. // Фармац. журн. - 2002. - №5. - С. 63-68.

17. Свєчнікова О.М., Ісаєв С.Г., Павлій О.І. та ін. // Вісник фармації. - 2002. - №3 (31). - 22-25.

18. Gaidukevich A.N., Svechnikova E.N., Dynnik E.V. et al. // Org. Reactivity. - 1990. - Vol. XXVII, issue 1 (97). P. 87-96.

19. Gaidukevich A.N., Svechnikova E.N., Kolesnik S.V. et al. // Org. Reactivity. - 1990. - Vol. XXVII, issue 3 (99). P. 152-158.

20. Свєчнікова О.М. Реакційна здатність, зв'язок структура-біологічна активність та використання похідних N-фенілантранілової кислоти: Дис. ... д-ра. хім. наук. - Х., 1999. - 299 с.

21. Альберт А., Сержент Е. Константы ионизации кислот и оснований. - М.: Химия, 1964. - 178 с.

22. Львовский Е.Н. Статистические методы построения эмпирических формул. - М.: Высш. шк., 1988. $125 \mathrm{c}$.

Надійшла до редакції 22.05.2013 p. 